\title{
PERFORMANSI JARINGAN FIBER OPTIK DARI SENTRAL OFFICE HINGGA KE PELANGGAN DI YOGYAKARTA
}

\section{PERFORMANCE OF FIBER OPTIC NETWORK FROM CENTRAL OFFICE TO USERS IN YOGYAKARTA}

\author{
Firdaus, Ferdyan Andhika Pradana, Eka Indarto \\ Jurusan Teknik Elektro, Universitas Islam Indonesia \\ firdaus@uii.ac.id
}

\begin{abstract}
Abstrak
Kebutuhan layanan komunikasi pada masa kini tidak hanya suara, melainkan juga data dan video. Maka diperlukan jaringan handal yang mampu memberikan performansi yang baik. Salah satu solusinya adalah jaringan fiber optik. Penelitian ini menganalisa power budget jaringan fiber optik milik PT. Telkom Indonesia di Yogyakarta yang meliputi 5 STO (Sentral Office) dan 20 Pelanggan. STO Terdiri dari STO Kalasan, STO Godean, STO Kotabaru, STO Bantul, dan STO Pugeran. 20 Pelanggan tersebar di wilayah STO Kotabaru, STO Bantul dan STO Pugeran. Berdasar pengukuran di peroleh nilai redaman total antara STO hingga ke pelanggan masih kurang dari 28 dB. Hasil tersebut sesuai dengan standar tetapan PT. Telkom Indonesia. Nilai redaman kabel adalah $0,26 \mathrm{~dB} / \mathrm{Km}$ masih sesuai dengan standart ITU (International Telecomunication Union) no. T-REC-G.651-199802-I. Jaringan mampu melayani pelanggan dengan kecepatan rata rata 8,23 Mbps untuk download dan 2,04 Mbps untuk upload.
\end{abstract}

Kata kunci : fiber optik, bandwidth, power budget

\begin{abstract}
Communication services today not only voice, but also data and video. It would require a reliable network that can provide good performance. One of the solution is a fiber optic network. This study analyzes the power budget fiber optic network owned by PT. Telkom Indonesia in Yogyakarta that includes 5 STO (Central Office) and 20 customers. The STO are Kalasan STO, Godean STO, Kotabaru STO, Bantul STO, and Pugeran STO. Then 20 Customers spread across Kotabaru STO, Bantul STO and Pugeran STO. Based on measurements obtained total attenuation between STO to the customer is still less than $28 \mathrm{~dB}$. These results are in accordance with the standard of PT. Telkom Indonesia. Cable attenuation is $0.26 \mathrm{~dB} / \mathrm{km}$, it is still in accordance with the ITU standard (International Telecommunications Union) no. T-REC-G.651-199802-I. The network is able to serve its customers with an average speed of $8.23 \mathrm{Mbps}$ for downloads and $2.04 \mathrm{Mbps}$ for upload.
\end{abstract}

\section{Keywords: fiber optic, bandwidth, power budget}

\section{PENDAHULUAN}

Kebutuhan layanan komunikasi pada masa kini tidak hanya suara, melainkan juga data dan video. Maka diperlukan jaringan handal yang mampu memberikan performansi yang baik, salah satunya adalah jaringan fiber optik. Jaringan yang mempunyai performansi sangat bagus dan handal akan memberikan dampak yang sangat positif kepada pelanggan, sehingga pelanggan puas dengan layanan yang disediakan oleh provider telekomunikasi. 
Penelitian ini akan menganalisa performansi jaringan optik dari sentral office hingga ke pelanggan di daerah Yogyakarta dengan parameter meliputi nilai redaman, loss sambungan, jarak kabel, redaman end to end, power level, dan continuitas. Pengambilan data ini akan menggunakan beberapa perangkat akses fiber optik yaitu OTDR (Optical Domain Reflecto Meter), Power Meter, Light Source (cahaya), BER Meter dan Variable Attenuator. Setelah mengambil data dan mendapat nilai parameternya maka akan dibandingan dengan standar yang sudah ditetapkan oleh PT Telkom Akses, kemudian memberikan solusi terbaik untuk kedepan agar performansi jaringan fiber optik lebih bagus.

Prinsip kerja dari sistem komunikasi serat optik ini adalah sinyal awal/source yang berbentuk sinyal listrik ini pada transmitter diubah oleh transducer elektro-optik (Dioda/Laser Dioda) menjadi gelombang cahaya yang kemudian ditransmisikan melalui kabel serat optik menuju penerima/receiver yang terletak pada ujung lainnya dari serat optic. Pada penerima/receiver sinyal optik ini diubah oleh transducer Opto-elektro (Photo Dioda/ Avalanche Photo Dioda) menjadi sinyal elektris kembali. Dalam perjalanan sinyal optik dari transmitter menuju receiver akan mengalami redaman cahaya di sepanjang kabel optik, diakibatkan karena adanya sambungan-sambungan kabel dan konektor-konektor di perangkatnya, oleh karena itu jika jarak transmisinya jauh maka diperlukan sebuah atau beberapa repeater yang berfungsi untuk memperkuat gelombang cahaya yang telah mengalami redaman sepanjang perjalanannya.

Ada beberapa komponen yang menjadi bahan pertimbangan dalam mendesain suatu jaringan optik. Salah satunya adalah rugi-rugi transmisi serat optik (attenuation). Rugi-rugi transmisi ini adalah salah satu karakterisktik yang penting dari serat optik. Rugi-rugi ini menghasilkan penurunan daya cahaya, penurunan bandwidth dari sistem, dan pengurangan kapasitas sistem secara keseluruhan. Rugi-rugi serat optik meliputi : rugi-rugi absorpsi, rugi-rugi pada inti dan cladding, rugi-rugi konektor dan splice.

Pengukuran atau power budget adalah suatu kegiatan yang dilakukan untuk mengetahui nilai dari parameter suatu kabel dan atau perangkat akses fiber optik. Parameter pengukuran atau power budget kabel fiber optik meliputi redaman, loss sambungan, jarak kabel, redaman end to end, dan power level. Adapun pengukuran perangkat aktif akses fiber optik meliputi power transmit, power reciever dan sensitivity. Peralatan yang digunakan untuk pengukuran kabel dan perangkat akses fiber optic diantaranya adalah OTDR dan power meter. Power meter yang mempunyai kemampuan pengukuran end to end passthrough splitter.

Sebelumnya telah diteliti tentang "Power Budget Analysis Of Broadcast Passive Optical Network" oleh Muhammad Faiz[1]. Pada penelitian ini dilakukan analisis power budget pada jaringan Fiber To The Home (FTTH) dengan topologi bus, star dan bus-star dengan mengukur beberapa parameter seperti fiber loss, coupling loss, splitter loss, detection method dan kualitas sinyal. Dari penelitian ini kita dapat mengetahui perhitungan link budget yang dibutuhkan dari beberapa topologi yang digunakan.

Penelitian selanjutnya tentang "Analisis Perhitungan dan Pengukuran Transmisi Jaringan Serat Optik Telkomsel Regional Jawa Tengah" telah dilakukan oleh Fazar Guntara Praja, Dwi Aryanta, Lita Lidyawati[2]. Pengujian jaringan dilakukan pada panjang gelombang $\lambda=1310 \mathrm{~nm}$ dan $\lambda=1550 \mathrm{~nm}$. Perancangan transmisi jaringan serat optik Telkomsel Regional Jawa Tengah terbentang diantara Kota Bawen-Payaman yang terdiri dari empat link. Pengukuran dilakukan pada power link budget dan rise time budget dengan ketentuan standar KPI (Key Performance Indicator) Telkomsel yaitu untuk power link budget sebesar $-4 \mathrm{dBm}$ dan rise time budget $70 \mathrm{ps}$. Hasil pengukuran link jaringan diperoleh nilai power link budet rata-rata sebesar $-0,33 \mathrm{dBm}$ dan rise time budget rata-rata sebesar 45,76 Ps, yang mengindikasikan seluruh link yang telah 
dibangun memiliki kinerja yang baik dan sesuai dengan standar minimal yang diinginkan Telkomsel.

Penelitian lain tentang "Analisa Redaman Serat Optik Terhadap Kinjera Sistem Komunikasi Serat Optik Menggunakan Metode Optical Link Power Budget” juga telah dilakukan oleh Endy Kusuma Wadhana dan Heru Setijono[3]. Pada penelitian ini telah dilakukan analisis redaman serat optik terhadap sistem komunikasi serat optik di jalur Rungkut ke Malang ruas Gempol di PT. Telkom Indonesia, Divisi SKSO Arnet SBT menggunakan kabel serat optik Single Mode Step Index tipe G.652. Alat bantu yang digunakan untuk pengambilan data pada penelitian ini adalah Power Meter, JDSU MTS 8000, dan perangkat NMS (Network Monitoring System) yang berfungsi untuk Monitoring level daya dari Rungkut ke Malang. Digunakan metode link power budget untuk mengetahui kinerja dari sistem komunikasi kabel serat optik akibat dari redaman yang terjadi di sepanjang kabel serat optik berdasarkan nilai daya ouput yang diterima di Receiver. Dari hasil penelitian ini didapatkan bahwa pada jalur Rungkut ke Malang ruas Gempol redaman tertinggi di sepanjang kabel serat optik jatuh di daerah gempol pada jarak $32.050 \mathrm{~km}$, dengan nilai redaman total $10.119 \mathrm{~dB}$, dan redaman per kilometer $0,34 \mathrm{~dB} / \mathrm{km}$.

Penelitian ini berbeda dari penelitian sebelumnya, penelitian ini lebih fokus pada jaringan fiber optik di daerah Yogyakarta dengan melakukan power budget. Penelitian ini akan menganalisa data yang diperoleh dari mengambil data dari sentral office hingga ke pelanggan di daerah Yogyakarta untuk mengetahui nilai redaman, loss sambungan, jarak kabel, redaman end to end, power level, dan continuitas. Pengambilan data ini akan menggunakan beberapa perangkat akses fiber optik yaitu OTDR dan power meter. Setelah mengambil data dan mendapat nilai parameternya maka akan dibandingan dengan standar yang sudah ditetapkan oleh PT Telkom Akses, kemudian memberikan solusi terbaik untuk kedepan agar performansi jaringan fiber optik lebih bagus dan tahan terhadap loss.

\section{METODOLOGI/PERANCANGAN}

Link Budget jaringan fiber optik GPON dari OLT sampai ONU/ONT adalah $28 \mathrm{~dB}$ atau ekuivalen dengan panjang fiber optik dari OLT sampai ONT maksimum $17 \mathrm{Km}$. Perhitungan bisa dilihat pada tabel 1 dan rumus dibawah ini[4].

Redaman $\mathrm{FO}=($ Panjang kabel FO $x$ standar redaman kabel $)+($ Jumlah Splitter $1: 4 x$ standar redaman splitter $1: 4)+($ Jumlah Splitter 1:8 x standar redaman splitter 1:8) + (Redaman UPC $x$ total UPC) + $($ Redaman $A P C+$ total $A P C)+($ redaman sambungan $O D C x$ jumlah sambungan $O D C)+$ (redaman sambungan $O D P x$ jumlah sambungan $O D P)+($ redaman sambungan drop kabel $x$ jumlah sambungan drop kabel)

$=(0,35 \times 17)+(7,25 \times 1)+(10,38 \times 1)+(0.25 \times 5)+(0,35 \times 2)+(0,1 \times 8)+(0,1 \times 2)+$ $(0,1 \times 2)$

Total $\quad=$ Redaman $\mathrm{FO}+$ Toleransi

$=26,73+1,27=28 \mathrm{~dB}$

Tabel 1. Total Redaman FO [7]

\begin{tabular}{|c|c|c|c|c|c|c|}
\hline No & \multicolumn{2}{|r|}{ URAIAN } & SATUAN & $\begin{array}{c}\text { STANDARD } \\
\text { REDAMAN (dB) }\end{array}$ & VOLUME & $\begin{array}{c}\text { TOTAL } \\
\text { REDAMAN (dB) }\end{array}$ \\
\hline 1 & \multicolumn{2}{|l|}{ Kabel Fo } & $\mathrm{km}$ & 0.35 & 17 & 5.95 \\
\hline \multirow{5}{*}{2} & \multirow{5}{*}{ Splitter } & 1:2 & $\mathrm{bh}$ & 3.70 & & \\
\hline & & $1: 4$ & bh & 7.25 & 1 & 7.25 \\
\hline & & $1: 8$ & bh & 10.38 & 1 & 10.38 \\
\hline & & $1: 16$ & bh & 14,10 & & \\
\hline & & $1: 32$ & bh & 17,45 & & \\
\hline \multirow{2}{*}{3} & \multirow{2}{*}{ Konektor } & SC/UPC & bh & 0.25 & 5 & 125 \\
\hline & & SC/APC: & bh & 0.35 & 2 & 0.7 \\
\hline \multirow{3}{*}{4} & \multirow{3}{*}{ Sambungan } & di Kabel Feeder & bh & 0.10 & 8 & 0.8 \\
\hline & & di Kabel Oistribusi & bh & 0,10 & 2 & 0.2 \\
\hline & & di Drop Kabel & bh & 0,10 & 2 & 0.2 \\
\hline \multicolumn{6}{|c|}{ TOTAL REDAMAN MURNI } & 26.73 \\
\hline \multicolumn{6}{|c|}{ TOTAL REDAMAN + TOLERANSI } & 28 \\
\hline
\end{tabular}

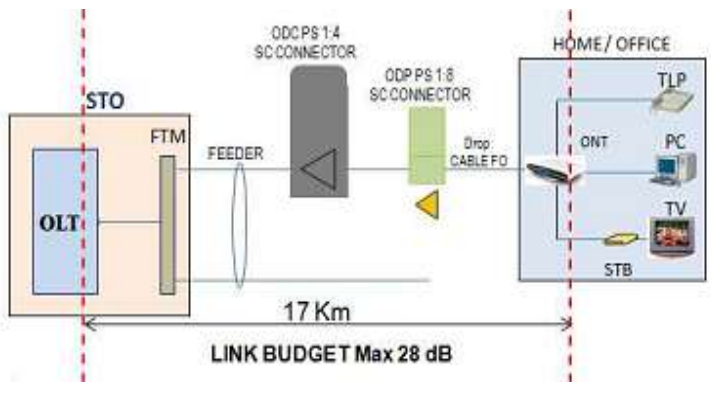

Gambar 1. Link budget maksimum [7] 
Dalam melakukan pengukuran link budget seperti gambar 1 digunakan beberapa alat ukur yaitu OTDR dan Power Meter. Alat tersebut merupakan alat yang sering digunakan PT. Telkom Akses untuk melakukan pengukuran[5].

\subsection{Optical Domain Reflecto Meter (OTDR)}

OTDR merupakan salah satu peralatan utama baik untuk kegiatan instalasi maupun pemeliharaan link fiber optic, bisa dilihat pada gambar 2. OTDR dipakai untuk mendapatkan gambaran visual dari redaman fiber optik sepanjang sebuah link yang diplot pada sebuah layar dengan jarak digambarkan pada sumbu $\mathrm{X}$ dan redaman pada sumbu Y. Pada jaringan yang menggunakan splitter, pengukuran dilakukan persegmen. Secara umum fungsi dari OTDR adalah mengukur redaman, mengukur loss sambungan, mengukur loss antar dua titik, mengukur jarak kabel, dan melokalisir gangguan. Informasi mengenai redaman, loss sambungan, loss konektor dan lokasi gangguan serta loss antara dua titik dapat diketahui dari display OTDR. Prinsip kerja dari alat ukur OTDR bisa dijelaskan sebagai berikut, OTDR memancarkan pulsapulsa cahaya dari sebuah sumber dioda laser ke dalam sebuah fiber optik dengan jarak yang sudah ditentukan atau hingga titik akhir jaringan fiber optik. Daya yang dipancarkan OTDR sudah ditetapkan pada setingan awal. Sebagian sinyal-sinyal dikembalikan ke OTDR, sinyal diarahkan melalui sebuah coupler ke detektor optik dimana sinyal tersebut diubah menjadi sinyal listrik dan ditampilkan pada layar.

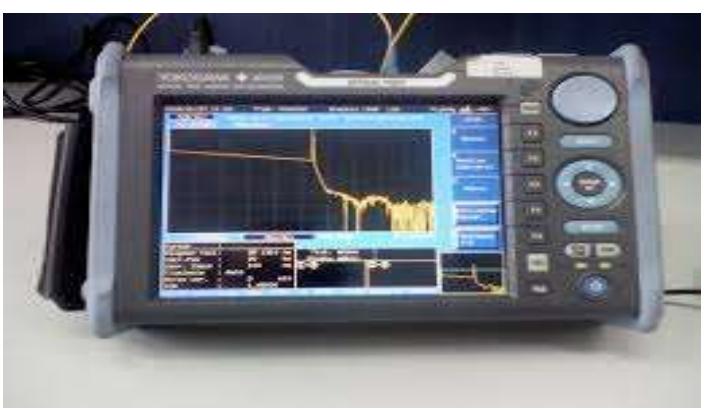

Gambar 2. OTDR [7]

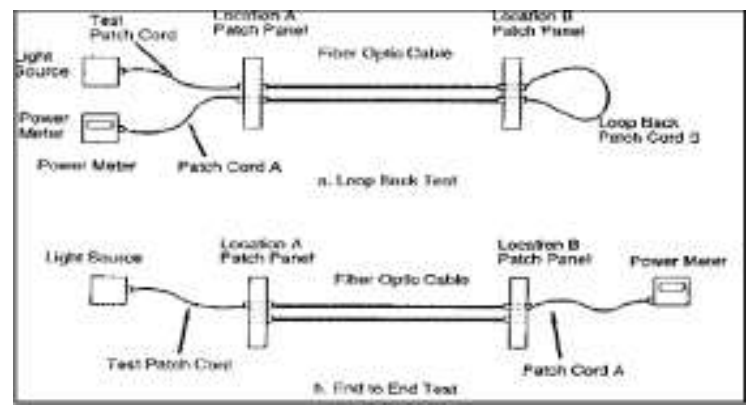

Gambar 3. Konfigurasi Pengukuran Link Optik [8]

\subsection{Power Meter}

Alat ukur ini dipakai untuk mengukur total loss dalam sebuah link optik baik saat instalasi (uji akhir) atau pemeliharaan. Redaman diukur dalam satuan decibel (dB). Loss atau redaman dinyatakan dalam $L(d B)=\operatorname{Pin}(d B m)-\operatorname{Pout}(d B m)$ atau $L(d B)=10 \times L o g($ Pin/ Pout $)$. Konfigurasi pengukuran suatu link optik bisa dilihat pada gambar 3.

Pada saat melakukan pengukuran atau pengetesan sering menggunakan patchcord, sehingga kondisi patchcord ini harus terjamin performansi dan kualitasnya. Setiap patchcord yang akan dipakai harus dites, hasil ukur patchcord dibandingkan dengan spesifikasi teknis pabrik, dan bersihkan seluruh konektor sebelum pengetesan dengan menggunakan kapas/tissue atau udara semprot seperti dush off. Beberapa hal yang harus diperhatikan saat mengoperasikan alat ukur Optical Power Meter yaitu dengan menggunakan panjang gelombang yang tepat, konektor yang tepat, jenis fiber yang dapat diukur adalah Single Mode dan Multi Mode. Setelah itu yang terakhir adalah melakukan kalibrasi. Gambar Optical Power Meter terlihat pada gambar 4.

\subsection{Pengetesan Jaringan Kabel Fiber Optik di Sentral Office}

Untuk mengetahui performansi kabel optik dapat menggunakan cara seperti dijelaskan pada gambar 5, menggunakan OTDR dan software TraceView. STO kalasan memiliki 4 port, 
masing-masing port terdiri dari 24 core, jadi tiap perangkat aktif tersebut memiliki 96 core. Kemudian 1 core itu sendiri dapat terbagi menjadi 4 di ODC karena adanya passive splitter 1:4 dan ditambah di ODP terdapat passive splitter 1:8 sehingga 96 core dapat melayani $96 \times 4 \times 8=$ 3072 pelanggan. Sedangkan STO godean memiliki 4 port yang tiap portnya hanya terdiri dari 12 core, sehingga total pelanggan yang terdapat di STO godean hanya 1536 pelanggan. Namun di STO godean banyak core digunakan untuk menghidupkan GPON di Node-B. Node-B itu sendiri adalah BTS untuk melayani layanan telekomunikasi 3G. Angka 3072 dan 1536 tersebut apabila semua core digunakan oleh pelanggan dan semua nya terpenuhi maka menjadi angka maksimum kapasitas.

\subsection{Gangguan-Gangguan Pada Jaringan Fiber Optik}

Gangguan pada jaringan optik antara lain gangguan pada konfigurasi bandwidth, gangguan di STO, gangguan pada ODC dan ODP, serta gangguan pada pelanggan. Gangguan pada konfigurasi yaitu pada settingan kapasitas bandwidth pelayanan, misalnya pelanggan ingin berlangganan $10 \mathrm{MB}$ namun pelanggan hanya menerima $2 \mathrm{MB}$ saja. Settingan tersebut hanya bisa dilakukan konfigurasi antara sentral office dan di pelanggan[6].

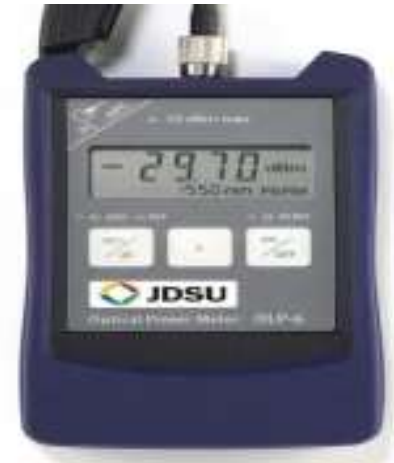

Gambar 4. Power Meter Fiber Optik [8]

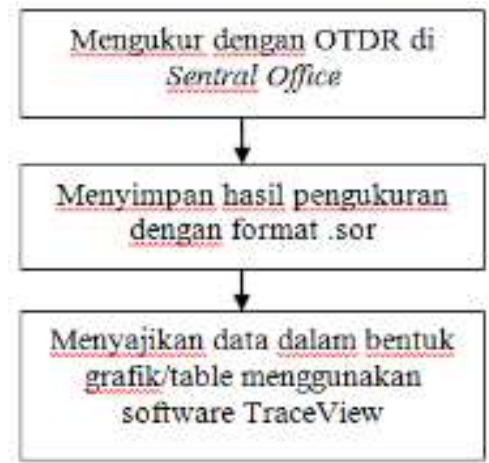

Gambar 5. Diagram proses pengolahan data menggunakan OTDR dan TraceView

Sedangkan gangguan pada ODC dan ODP biasanya hanya berupa gangguan kabel putus, adapter kabel patchcord yang kendor atau tidak pas sehingga terjadi bias cahaya, kemudian gangguan kerusakan passive spiltter. Gangguan di pelanggan biasanya karena kabelnya terlipat sehingga fiber atau kaca di dalam kabel tersebut pecah, kabel fiber optik tertimpa benda dengan waktu yang cukup lama sehingga menyebabkan performansi jaringan tidak maksimal. Gangguan yang paling banyak terjadi adalah gangguan dari faktor alam, misalnya ada angin kencang, pohon tumbang, kabel dimakan tikus, dan hewan hewan lain yang bisa menyebabkan kerusakan kabel fiber optik.

\section{PEMBAHASAN}

Pada bab ini akan dibahas performa jaringan fiber optik yang ada di Yogyakarta. Data yang akan dibahas berupa link power budget dan data lapangan. Link power budget itu sendiri mencakup Pin, Pout, dan redaman total pengukuran sedangkan untuk data lapangan mencakup panjang kabel, redaman splicing, redaman connector, dan redaman splitter. Selanjutnya untuk pengukuran pada sentral office, diukur 5 STO yaitu STO kalasan, STO godean, STO Pugeran, STO Kotabaru, dan STO Bantul. Kemudian diambil sejumlah 20 pelanggan yang menggunakan pelayanan fiber optik. Untuk melakukan pengukuran di STO menggunakan alat ukur OTDR sedangkan untuk melakukan pengukuran di pelanggan menggunakan alat ukur OTDR dan Power Meter. 


\subsection{Data Transmit Perangkat Aktif}

Hasil pengukuran menggunakan OTDR pada STO bisa dilihat pada gambar 6 sampai gambar 9, sumbu-x adalah daya $(\mathrm{dB})$ dan sumbu-y adalah jarak $(\mathrm{km})$.

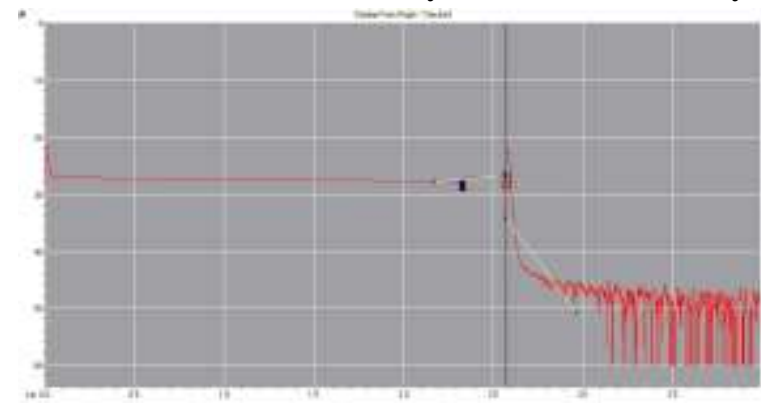

Gambar 6. Power Core 1 STO Kalasan

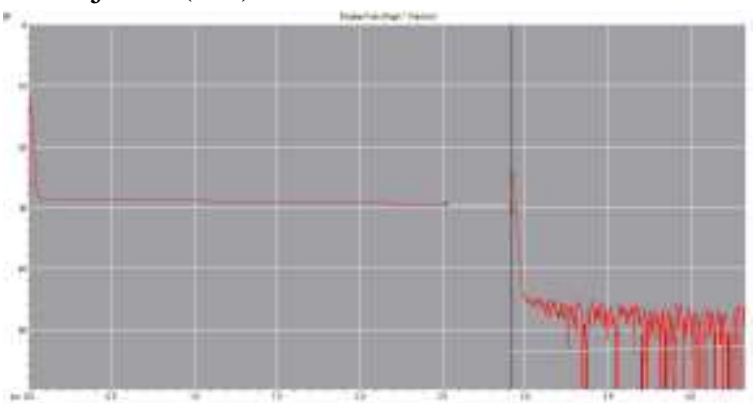

Gambar 7. Power Core 19 STO Godean

Gambar 6 menunjukan bahwa pada titik $0 \mathrm{~km}$ tersebut terdapat kurva, kurva pertama itu dinamakan deathzone. Pada titik 2,57 km terdapat event dengan terputusnya kabel fiber optik di lokasi tersebut. Kurva tersebut menjadi drop kebawah sehingga membentuk bias-bias kurva dari alat ukur OTDR. Gambar 7 menunjukan bahwa pada titik $0 \mathrm{~km}$ tersebut terdapat kurva, kurva pertama itu dinamakan detson yaitu zona mati. Pada titik $2,91 \mathrm{~km}$ terdapat event dengan terputusnya kabel fiber optik di lokasi tersebut. Kurva tersebut menjadi drop kebawah sehingga membentuk bias-bias kurva dari alat ukur OTDR.

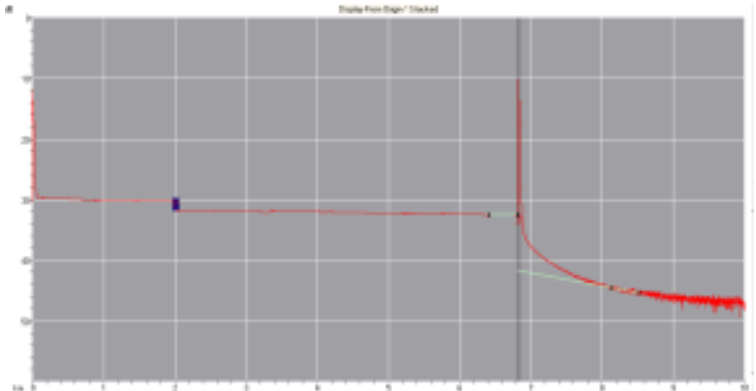

Gambar 8. Power Core 25 STO Kotabaru

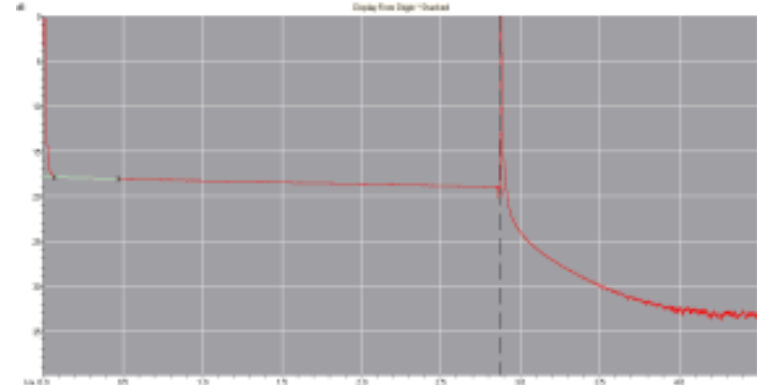

Gambar 9. Power Core 15 STO Bantul

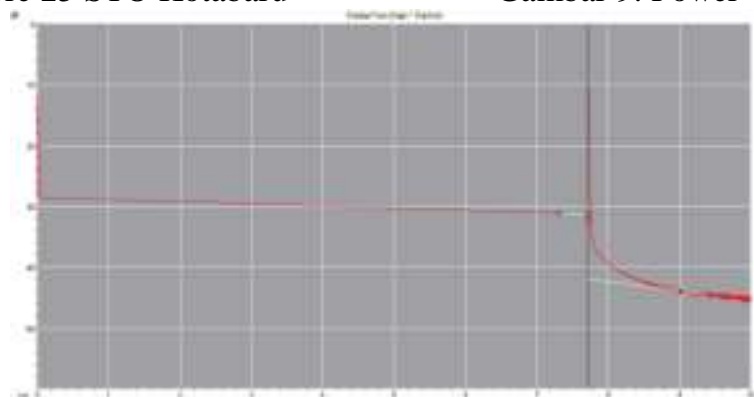

Gambar 3.10 Power Core 23 STO Pugeran

Gambar 8 menunjukkan bahwa tidak ada kabel yang terputus, dan jarak dari STO Kotabaru hingga ke ODC selanjutnya adalah $6,82 \mathrm{Km}$ untuk ke dua core tersebut. Di dalam core 25 tersebut hanya terdapat 1 sambungan yaitu di titik masuk ke ODC (titik 2,016 Km) dengan loss end to end total sebesar 2,89 dB. Pada gambar 9 dapat diketahui bahwa kabel tidak ada yang terputus, dan jarak dari STO Bantul hingga ke ODC selanjutnya 2,89 Km. Di dalam core tersebut tidak ada sambungan sama sekali, sehingga total panjang nya $2,89 \mathrm{Km}$ dan total loss end to end fiber optiknya adalah 1,57 dB di dapat dari nilai yang tertera di OTDR. Pada gambar 10 dapat diketahui bahwa kabel tidak ada yang terputus, dan jarak dari STO Pugeran hingga ke ODC selanjutnya 
adalah 7,71 Km. Di dalam core tersebut hanya terdapat 1 sambungan yaitu di titik masuk ke ODC (titik 7,33 Km) sehingga total loss sampai end to end adalah 2,98 dB.

\subsection{Data di Sisi Pelanggan}

Rute jaringan dari STO ke ODC ke ODP hingga ke pelanggan. Panjang kabel dari STO sampai ODC mencapai $2 \mathrm{~km}$ hingga $20 \mathrm{~km}$ menggunakan kabel feeder, dan kabel dari ODC hingga ODP mencapai 0,5 km hingga $4 \mathrm{~km}$ menggunakan kabel distribusi. Kabel dari ODP hingga pelanggan hanya 50 meter sampai 500 meter menggunakan kabel jenis drop. Pada ODC terdapat pasif splitter 1:4 dengan redaman sebesar $-7,45 \mathrm{~dB}$ dan di ODP terdapat pasif splitter 1:8 dimana dengan redaman sebesar $-10,25 \mathrm{~dB}$. Kabel juga mempunyai redaman sebesar $0,35 \mathrm{~dB} / \mathrm{km}$. Redaman sambungan (splicing) sebesar 0,1 dB. Redaman connector sebesar 0,25 dB. Dalam pengukuran ini terdapat 3 splicing yaitu di ODC, ODP, dan di pelanggan. Terdapat 3 connector di ODC, ODP, dan di pelanggan.

$R T($ redaman total $)=R K+R S g+R C+R S p+R S p 1$

$\mathrm{RK}$ adalah redaman kabel $=0,35 \mathrm{~dB} \times$ (Total Panjang Kabel) $\mathrm{Km}$. RSg adalah Redaman splicing $=0,1 \mathrm{~dB} \times 3=0,3 \mathrm{~dB}$. RC adalah Redaman connector $=0,25 \mathrm{~dB} \times 3=0,75 \mathrm{~dB}$. RSp adalah Redaman splitter ODC $=7,45 \mathrm{~dB} \times 1=7,45 \mathrm{~dB}$. RSp1 adalah Redaman splitter ODP $=$ $10,38 \mathrm{~dB} \times 1=10,38 \mathrm{~dB}$. Untuk splitter di masing masing ODC dan ODP hanya terdapat 1 . Data link budget dapat dilihat pada tabel 2 dan tabel 3 .

Tabel 2. Data di Sisi Pelanggan di STO Bantul dan

Tabel 3. Data di Sisi Pelanggan di STO Kotabaru STO Pugeran

\begin{tabular}{|c|c|c|c|c|c|c|c|c|c|c|c|c|c|}
\hline No & Pelanggan & $\begin{array}{c}\begin{array}{c}P \text { in } \\
(\mathrm{dBm})\end{array} \\
\end{array}$ & $\begin{array}{l}\text { P out } \\
\text { (dBm) }\end{array}$ & $\begin{array}{c}\text { RT } \\
\text { Pengukaran } \\
\text { (dB) }\end{array}$ & $\begin{array}{c}\text { Panjang } \\
\text { Kabe! } \\
\text { (Km) }\end{array}$ & $\begin{array}{c}\text { RK } \\
\text { Perhituagas } \\
\text { (dB/Km) }\end{array}$ & No & Pelanggan & $\begin{array}{c}P \text { in } \\
(d B m)\end{array}$ & $\begin{array}{l}P \text { out } \\
(\mathrm{dBm})\end{array}$ & $\begin{array}{c}\text { RT } \\
\text { Peagukuran } \\
\text { (dB) }\end{array}$ & $\begin{array}{c}\text { Panjang } \\
\text { Kabel } \\
(\mathrm{Km})\end{array}$ & $\begin{array}{c}\text { RK } \\
\begin{array}{c}\text { Perhitungan } \\
(\mathrm{dB} / \mathbf{K} \mathbf{m})\end{array}\end{array}$ \\
\hline 1 & $\begin{array}{l}\text { SMA Muh } \\
\text { Pletet }\end{array}$ & 2,01 & $-20,08$ & 22,09 & 15,12 & 0.27 & \multirow[b]{2}{*}{1} & \multirow[b]{2}{*}{ Akper } & \multirow{2}{*}{3,92} & \multirow{2}{*}{$-18,11$} & \multirow{2}{*}{$-22,03$} & \multirow{2}{*}{14,87} & \multirow[t]{2}{*}{0,21} \\
\hline & $5 \mathrm{MKN} 2$ & 3,11 & $-19,00$ & $-22,11$ & 11,48 & 0,28 & & & & & & & \\
\hline 2 & Senvon & & & & & & \multirow{2}{*}{2} & AMA & 3,21 & $-19,67$ & $-22,88$ & 15,38 & \multirow[t]{2}{*}{0.26} \\
\hline 3 & [5] & 4.75 & $-19,33$ & $-24,08$ & 15.02 & 0.34 & & & 245 & 1861 & 2106 & 1369 & \\
\hline & SMK & & & & & & 3 & RM Cirebon & 2,42 & $-18,61$ & $-21,00$ & 19,08 & 0,10 \\
\hline 4 & $\begin{array}{l}\text { Mr'avif } \\
\text { Kretek }\end{array}$ & 2,21 & $-18,96$ & $-21,17$ & 9,91 & 0,23 & 4 & $\begin{array}{l}\text { Tokoko Liman } \\
\text { Malioboro }\end{array}$ & 2,54 & $-19,32$ & $-21,86$ & 13,21 & 0,22 \\
\hline 5. & $\begin{array}{l}\text { SMRN 1 } \\
\text { Pyyugan }\end{array}$ & 3,19 & $-18,54$ & $.21,33$ & 10,87 & 0,26 & 5 & UAD & 3,09 & $-19,10$ & $-22,19$ & 13.91 & 0,24 \\
\hline 6 & $\begin{array}{l}\begin{array}{l}\text { SMKN 1 } \\
\text { Kalusun }\end{array} \\
\text { SMK }\end{array}$ & 455 & $-18,46$ & $-23,01$ & 12,16 & 0,33 & 6 & $\begin{array}{c}\text { Dinas } \\
\text { Pariwisata }\end{array}$ & 3.65 & -19.46 & $-23,11$ & 12,21 & 0,34 \\
\hline 7 & $\begin{array}{c}\text { Dipontegcoo } \\
\text { Tajem }\end{array}$ & 2,98 & $-18,04$ & $-21,02$ & 7,16 & 0,29 & 7 & $\begin{array}{c}\text { Mall } \\
\text { Matioboro }\end{array}$ & 3,67 & $-19,61$ & $-23,28$ & 13,75 & 0,31 \\
\hline 8 & $\begin{array}{l}\text { Perumahan } \\
\text { Alam Citsn }\end{array}$ & 456 & $-18,32$ & $-22,88$ & 14,21 & 0,28 & 8 & $\begin{array}{l}\text { SMAN } 1 \\
\text { Pivungan }\end{array}$ & 2.55 & $-19,42$ & $-21,97$ & 13,41 & 0,23 \\
\hline 9 & $\begin{array}{c}\text { Mrs HA } \\
\text { Bantul }\end{array}$ & 4,98 & $-16,97$ & 21,95 & 11,09 & 0.27 & 9 & UKDW & 4,27 & $-18,56$ & $-22,83$ & 12.76 & 0,30 \\
\hline 10 & $\begin{array}{l}\text { SMER Puira } \\
\text { Tama } \\
\text { Bantul }\end{array}$ & 3,13 & $-20,32$ & $-23,45$ & 13,59 & 0,33 & 10 & $\begin{array}{c}\text { MAN } \\
\text { Wonolaramo }\end{array}$ & 2,01 & $-20,05$ & $-22,09$ & 15,12 & 0,21 \\
\hline
\end{tabular}

Tabel 4. Download dan Upload Layanan Pelanggan

\begin{tabular}{|c|c|c|c|c|c|c|c|}
\hline \multirow[t]{2}{*}{ No } & \multirow{2}{*}{ Pelanggan } & \multirow{2}{*}{$\begin{array}{c}\text { Nilu } \\
\text { Redama } \\
\text { (dB) }\end{array}$} & \multicolumn{2}{|c|}{$\begin{array}{l}\text { Download } \\
\text { (MBps) }\end{array}$} & \multicolumn{2}{|c|}{ Upload (MBps) } & \multirow{2}{*}{$\begin{array}{l}\text { Jam } \\
\text { Sibuk }\end{array}$} \\
\hline & & & HP & Laptop & HP & Laptop & \\
\hline 1 & $\begin{array}{l}\text { SMKN1 } \\
\text { Piyungan }\end{array}$ & $-21,97$ & 7,21 & 8.91 & 1,02 & 2,10 & 10.05 \\
\hline 2 & Akper & $-22,03$ & 7,78 & 8,57 & 1,12 & 2,03 & 11.35 \\
\hline 3 & UAD & $-22,19$ & 6,65 & 787 & 0,98 & 1,94 & 1456 \\
\hline 4 & AMA & $-22,88$ & 6,19 & 8,12 & 0,91 & 1,87 & 13.41 \\
\hline 5 & ISI & $-21,17$ & 8,12 & 9.02 & 1,09 & 2,67 & 16.43 \\
\hline 6 & Mall Malioboro & $-23,28$ & 5,26 & 6.93 & 0,52 & 1.68 & 1702 \\
\hline
\end{tabular}


Untuk standar umum di jaringan fiber optik $\mathrm{P}$ in adalah $2 \mathrm{~dB}$ hingga $7 \mathrm{~dB}$. $\mathrm{P}$ out atau final value ke pelanggan maksimum $-28 \mathrm{~dB}$, sehingga bila masih di bawah itu dapat dikatakan kualitas jaringan fiber optik sudah bagus sesuai standar. Jarak maksimum kabel dari STO hingga pelanggan adalah $17 \mathrm{Km}$. Besarnya data rate layanan yang digunakan (wifi.id) bisa dilihat pada tabel 4, untuk download bisa mencapai 9 Mbps dan untuk upload bisa mencapai 2 Mbps.

\section{KESIMPULAN}

Hasil pengukuran link jaringan keseluruhan yang diperoleh nilai redamannya kurang dari $28 \mathrm{~dB}$, yang mengindikasikan seluruh jaringan fiber optik di wilayah Yogyakarta telah dibangun memiliki kinerja sesuai standar yang diinginkan PT. Telkom Indonesia. Pengukuran untuk jarak STO ke ODC, ODC ke ODP, dan ODP ke pelanggan secara keseluruhan sudah memenuhi range standar PT. Telkom Indonesia yaitu untuk STO ke ODC maksimal jarak adalah $20 \mathrm{Km}$ menggunakan kabel feeder. Selanjutnya untuk jarak ODC ke ODP adalah 0,5 Km hingga $4 \mathrm{Km}$ menggunakan kabel distribusi. Dan untuk jarak ODP ke pelanggan adalah 50 meter hingga 500 meter menggunakan kabel drop.

Dengan memperhatikan nilai redaman kabel sesuai standar dari ITU (International Telecomunication Union) no. T-REC-G.651-199802-I yaitu $0,35 \mathrm{~dB} / \mathrm{Km}$, nilai redaman pengukuran real ternyata kurang dari $0,35 \mathrm{~dB} / \mathrm{Km}$, dengan rata rata redaman sebesar $0,266 \mathrm{~dB} / \mathrm{Km}$. Dengan demikian jaringan fiber optik di daerah Yogyakarta tepat dan memenuhi standart internasional.

Kualitas pelyanan fiber optik sudah sangat baik, hal ini dibuktikan dengan speed test yang dilakukan di beberapa pelanggan nilai Download dan Upload meskipun dalam jam sibuk atau dalam hal ini banyak pengguna yang mengakses layanan wifi id, namun nilai bandwidth nya masih sesuai dan mendekati nilai 10MB yang sudah diberikan oleh PT. Telkom Indonesia.

\section{Daftar Pustaka:}

[1] Faiz, M. 1999. Power Budget Analysis Of Broadcast Passive Optical Network. Tesis pada Universiti Teknologi Tun Hussein Onn

[2] Praja, F G. Aryanta, D. Lidyawati, L. 2011. Analisis Perhitungan dan Pengukuran Transmisi Jaringan Serat Optik Telkomsel Regional Jawa Tengah.

[3] Wadhana, Kusuma, E. dan Setijono, H. 2008. Analisa Redaman Serat Optik Terhadap Kinerja Sistem Komunikasi Serat Optik Menggunakan Metode Optical Link Power Budget.

[4] Keiser, G. 2006. FTTX concepts and applications. New Jersey: Jonh Wiley \& Son,Inc.

[5] Telkom Indonesia, P.T. 2004. Optical Access Network. Bandung: PT Telekomunikasi Indonesia, Tbk.

[6] Telkom Indonesia, P.T. 2013. Operation Maintenance Jaringan FTTH. Bandung: PT Telekomunikasi Indonesia, Tbk.

[7] Telkom Indonesia, P.T. 2013. Pedoman Desain Jaringan FTTH. Bandung: PT Telekomunikasi Indonesia, Tbk.

[8] Telkom Indonesia, P.T. 2013. Pedoman Pemasangan Instalasi Jaringan FTTH. Bandung: PT Telekomunikasi Indonesia, Tbk.

[9] Nugroho, A. 2011. Teknologi Gigabit-Capabel Passive Optical Network (GPON) Sebagai Triple Play Service. Makalah Seminar Kerja Praktek, Teknik Elektro Universitas Diponegoro. 